\title{
Re-Os systematics of high-Mg andesites and basalts from the Setouchi volcanic belt, SW Japan: Implications for interaction between wedge mantle and slab-derived melt
}

\author{
KATSUHIKO SUZUKI* and YoshIYUKI TATSUMI \\ Institute for Research on Earth Evolution (IFREE), Japan Agency for Marine-Earth Science and Technology (JAMSTEC), \\ Yokosuka 237-0061, Japan
}

(Received March 4, 2005; Accepted December 19, 2005)

\begin{abstract}
High-Mg andesites (HMAs) and basalts in the Setouchi volcanic belt exhibit large variations in both Os abundance and Os isotopic composition. For HMAs, ${ }^{187} \mathrm{Os} /{ }^{188} \mathrm{Os}$ ratios and Os concentrations range from 0.1718 to 0.2041 and from 8.1 to $11.5 \mathrm{ppt}$, respectively. For basalts, ${ }^{187} \mathrm{Os} /{ }^{188} \mathrm{Os}$ ratios and Os concentration range from 0.1556 to 0.1769 and from 31.0 to $53.7 \mathrm{ppt}$, respectively. The measured ${ }^{187} \mathrm{Os} /{ }^{188} \mathrm{Os}$ ratios are higher than that of the primitive upper mantle estimate. The petrological and geochemical characteristics of HMAs do not support a scenario whereby HMA magmas are derived from basalt magmas via assimilation-fractional crystallization processes within the crust. Instead, the observed elevated Os isotopic compositions may be explained by mixing between the wedge mantle and partial melts from subducted sediments, rather than slab-derived fluids.
\end{abstract}

Keywords: Re-Os isotope, Setouchi, high Mg andesite, subduction, slab melting

\section{INTRODUCTION}

The unique geochemical characteristics of subduction zone magmas have long been attributed to recycling of components from the subducting slab into the overlying mantle wedge source. However, the relative importance of different mechanisms by which this material transfer may occur remains unclear, as do the factors controlling which mechanisms dominate. Melting of the descending lithospheric slab may have occurred during subduction in Archean time due to steep mantle geothermal gradients. Since first proposed by Nicholls and Ringwood (1973) many petrologists have thus favored a mechanism involving slab melting and reaction of these melts with the overlying mantle wedge (e.g., Kay, 1978; Sekine and Wyllie, 1982; Brophy and Marsh, 1986; Martin, 1987; Defant and Drummond, 1990; Keleman, 1995). Alternatively, fluids produced by dehydration reactions in the subducting lithosphere may cause partial melting and metasomatism in the mantle wedge (e.g., Coats, 1962). In most modern subduction zones, these aqueous fluids are the most probable cause of melting of the overlying mantle wedge (e.g., Tatsumi and Eggins, 1995), as melting of the oceanic crust is not likely to occur (Peacock, 1990). Whether direct slab melting or slab dehydration

\footnotetext{
*Corresponding author (e-mail: katz@jamstec.go.jp)
}

Copyright @ 2006 by The Geochemical Society of Japan. occurs, Os isotopes are a potentially useful tracer for detecting subduction components in arc magmas because crustal materials, including oceanic crust and sediments, have much higher Re/Os and ${ }^{187} \mathrm{Os} /{ }^{188} \mathrm{Os}$ ratios (Esser and Turekian, 1993; Ravizza, 1993; Peucker-Ehrenbrink et al., 1995) than upper mantle peridotite (e.g., Meisel et al., 2001).

The behavior of Re and Os in the subduction environment is poorly constrained. Peridotite xenoliths with higher Os isotopic compositions (up to 0.156) than the hypothetical Primitive Upper Mantle (PUM) Os isotopic ratio of 0.1296 (Meisel et al., 2001) have been found in arc and back-arc settings (Brandon et al., 1996, 1999; McInnes et al., 1999; Becker et al., 2001; Widom et al., 2003). Most of the researchers proposed that these high ${ }^{187} \mathrm{Os} /{ }^{188} \mathrm{Os}$ ratios may result, at least in part, from the contribution of slab-derived components, while some argued it possibly attributed to crustal contamination. Several studies have recently reported that primitive arc lavas possess elevated Os isotope ratios of 0.128-3.70 (Alves et al., 1999, 2002; Borg et al., 2000; Lassiter and Luhr, 2001; Suzuki and Tatsumi, 2001; Hart et al., 2002; Woodland et al., 2002). Alves et al. $(1999,2002)$ and Borg et al. (2000) suggested that these radiogenic ${ }^{187} \mathrm{Os} /{ }^{188} \mathrm{Os}$ ratios reflect the variable input of slab-derived materials. Fluids have been shown experimentally to be able to transport Os (e.g., Suzuki et al., 2003) and Brandon et al. (1996) suggested that high $f_{\mathrm{H} 2 \mathrm{O}}$ and $f_{\mathrm{HCl}}$ in a slab-derived fluid may increase Os mobility in subduction zone envi- 
ronments. However, Becker (2000) considered that Os is not significantly lost from the subducting slab via dehydration processes, on the basis of similar Os abundances in eclogites and blueschists to those in MORB.

Contribution to the sub-arc mantle by overlying crust with highly radiogenic Os isotopes could also produce high ${ }^{187} \mathrm{Os} /{ }^{188} \mathrm{Os}$ ratios (Hart et al., 2002). Lassiter and Luhr (2001) have suggested that late stage contamination of primitive arc magmas by crustal material during assimilation/fractional crystallization (AFC) processes is the dominant route by which the Os isotopic signatures of the Mexican primitive arc volcanic rocks were generated. Borg et al. (2000) also attempted AFC modeling for the Cascade arc lavas, but they could not explain correlations between Os and other isotopes and therefore favored the hypothesis that slab-related material input contributed to the correlations.

High magnesian andesites (HMAs) can occur in subduction zone settings. The high $\mathrm{Mg} / \mathrm{Fe}$ ratios of HMAs provide evidence for their equilibration with upper mantle peridotite (Sato, 1977; Kuroda et al., 1978; Jenner, 1981; Crawford et al., 1989). Melting experiments in both synthetic peridotite systems (e.g., Kushiro, 1969, 1972) and using natural HMAs (Tatsumi, 1981, 1982; Umino and Kushiro, 1989; van Der Laan et al., 1989) confirmed that hydrous melting of peridotite can yield HMAs. Such hydrous upper mantle conditions can be attained through addition of fluids released during dehydration of the subducting slab (Crawford et al., 1989; Tatsumi and Maruyama, 1989). Alternatively, interaction between slabderived hydrous silicic partial melts and overlying mantle wedge peridotite has also attracted recent attention as a mechanism for HMA formation (Kay, 1978; Pearce et al., 1992; Yogodzinski et al., 1994; Kelemen, 1995; Hanyu et al., 2002; Tatsumi and Hanyu, 2003). Magmatism in the Setouchi volcanic belt (SVB) may provide an excellent example for such unusual tectonic conditions, as the lithosphere being subducted beneath the region was created at 27-15 Ma (Okino et al., 1994; Tamaki et al., 1999), immediately prior to the Setouchi magmatism at $13 \mathrm{Ma}$. As such, the subducting oceanic crust may have been sufficiently hot for partial melting to have occurred (Furukawa and Tatsumi, 1999; Peacock and Wang, 1999). In addition, opening of the backarc basin behind the SW Japan arc at 28-14 Ma (Kaneoka et al., 1992; Tada and Tamaki, 1992; Tamaki et al., 1992) may have resulted in unusually high temperature conditions in the mantle wedge (Tatsumi and Maruyama, 1989; Kimura et al., 2003).

Shimoda et al. (1998) reported $\mathrm{Pb}-\mathrm{Nd}-\mathrm{Sr}$ isotopic compositions for HMAs and basalts from the SVB and demonstrated a significant contribution from a subducted sediment component to the HMA magma source. Furthermore,

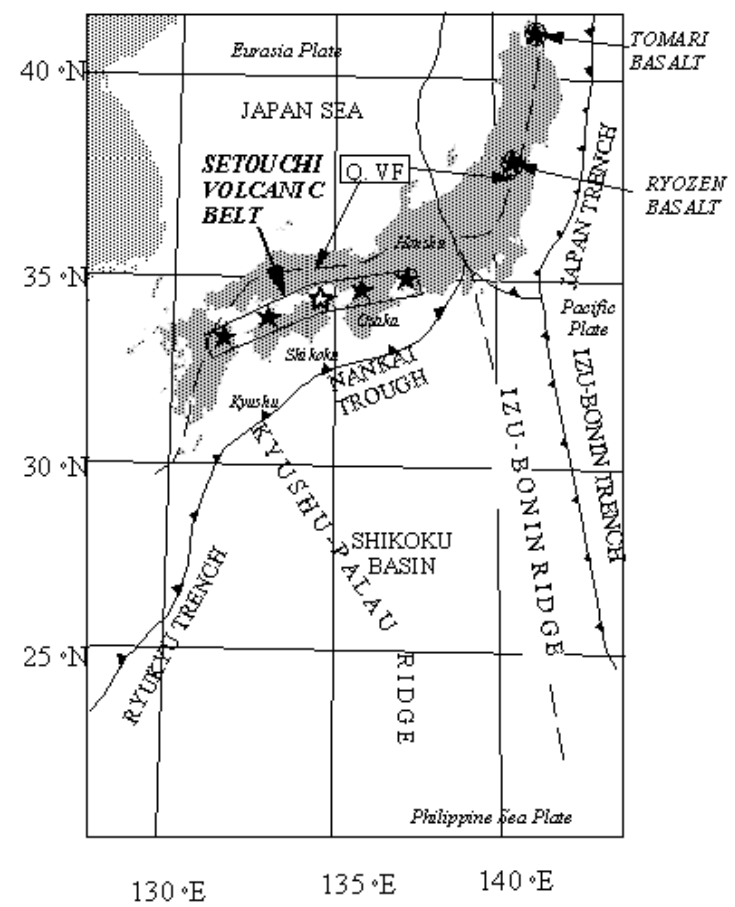

Fig. 1. A tectonic map of the SW Japan arc (modified from Shimoda et al., 1998). The Setouchi volcanic belt is located in the forearc region of the $S W$ Japan arc, i. e., trench-side of the Quaternary volcanic front $(Q . V F)$. The central three subprovinces of the volcanic belt in Shikoku and Osaka are characterized by the occurrence of HMAs. The samples analyzed in this study were collected from the area shown by an open star in the SVB.

the results of mixing calculations using an inferred original mantle composition and local oceanic sediments led Shimoda et al. (1998) to conclude that a sediment-derived melt, rather than aqueous fluids or oceanic crustderived melts, could have served as a plausible metasomatic agent for the HMA magma source. This was further supported by the results of geochemical modeling of partial melting of sediments and altered MORB and melt-solid interactions (Tatsumi, 2001; Tatsumi and Hanyu, 2003). A sediment-melt produced at $1050^{\circ} \mathrm{C}$ and 1.0 GPa changes its composition from rhyolitic to andesitic as it dissolves olivine and clinopyroxene from peridotite in the mantle wedge and crystallizes orthopyroxene to generate HMA (Tatsumi, 2001; Tatsumi and Hanyu, 2003).

In this study, we report Re and Os concentrations and Os isotopes for Setouchi HMAs and basalts from SW Japan. Ryozen and Tomari basalts from NE Japan are also analyzed for comparison. We then examine the contribution of slab-derived melts to the genesis of HMA and basalt magmas in the SVB. 
Table 1. Major element compositions of samples

\begin{tabular}{|c|c|c|c|c|c|c|c|c|}
\hline \multirow[b]{2}{*}{$\begin{array}{l}\text { Sample } \\
\text { Rock type }\end{array}$} & \multicolumn{6}{|c|}{ Setouchi } & \multicolumn{2}{|c|}{ Miocene NE Japan } \\
\hline & $\begin{array}{l}\text { SD SYB } \\
\text { basalt }\end{array}$ & $\begin{array}{l}\mathrm{SD} 424 \\
\text { basalt }\end{array}$ & $\begin{array}{c}\text { SD-261 } \\
\text { HMA }\end{array}$ & $\begin{array}{l}\text { SD407 } \\
\text { HMA }\end{array}$ & $\begin{array}{l}\text { SD411 } \\
\text { HMA }\end{array}$ & $\begin{array}{r}\text { JA-2 } \\
\text { HMA }\end{array}$ & $\begin{array}{l}\text { RZ-5 } \\
\text { basalt }\end{array}$ & $\begin{array}{l}\text { TM-0 } \\
\text { basalt }\end{array}$ \\
\hline $\mathrm{SiO}_{2}$ & 49.20 & 48.79 & 55.73 & 56.99 & 55.80 & 56.18 & 48.46 & 49.24 \\
\hline $\mathrm{TiO}_{2}$ & 1.01 & 0.97 & 0.71 & 0.60 & 0.61 & 0.67 & 0.62 & 0.5 \\
\hline $\mathrm{Al}_{2} \mathrm{O}_{3}$ & 15.31 & 13.46 & 15.44 & 15.63 & 15.41 & 15.32 & 14.35 & 14.1 \\
\hline $\mathrm{Fe}_{2} \mathrm{O}_{3} *$ & 2.77 & 2.27 & 2.27 & 2.01 & & & 2.53 & 9.04 \\
\hline $\mathrm{FeO}$ & 6.28 & 6.76 & 4.13 & 4.27 & & & 6.76 & \\
\hline $\mathrm{MnO}$ & 0.16 & 0.18 & 0.13 & 0.14 & 0.14 & 0.11 & 0.18 & 0.17 \\
\hline $\mathrm{MgO}$ & 11.55 & 10.59 & 7.21 & 7.75 & 7.77 & 7.68 & 13.62 & 12.31 \\
\hline $\mathrm{CaO}$ & 8.81 & 10.09 & 6.99 & 6.95 & 6.92 & 6.48 & 10.19 & 10.29 \\
\hline $\mathrm{Na}_{2} \mathrm{O}$ & 2.57 & 2.46 & 2.82 & 2.88 & 2.64 & 3.08 & 1.77 & 1.9 \\
\hline $\mathrm{K}_{2} \mathrm{O}$ & 1.27 & 1.35 & 2.21 & 2.35 & 2.42 & 1.80 & 0.25 & 0.63 \\
\hline $\mathrm{P}_{2} \mathrm{O}_{5}$ & 0.22 & 0.23 & 0.14 & 0.15 & 0.16 & 0.15 & 0.09 & 0.1 \\
\hline Total & 99.15 & 97.15 & 97.78 & 99.72 & 98.71 & 98.42 & 98.82 & 98.28 \\
\hline $\mathrm{FeO} * / \mathrm{MgO}$ & 0.78 & 0.78 & 0.90 & 0.81 & 0.79 & 0.81 & 0.93 & 0.93 \\
\hline${ }^{87} \mathrm{Sr} /{ }^{86} \mathrm{Sr}$ & 0.70439 & 0.70408 & 0.70490 & 0.70502 & 0.70491 & 0.70621 & & \\
\hline$\varepsilon_{\mathrm{Nd}}$ & +2.1 & +3.7 & +1.2 & +1.7 & +1.5 & -1.7 & & \\
\hline${ }^{206} \mathrm{~Pb} /{ }^{204} \mathrm{~Pb}$ & 18.314 & 18.298 & 18.369 & 18.361 & 18.367 & 18.394 & & \\
\hline
\end{tabular}

Data are from Shimoda et al. (1998).

\section{Geological SETTING AND SAMPLES}

The Philippine Sea plate is actively subducting beneath the Eurasian plate to form the arc-trench system of SW Japan (Fig. 1). Although the clearly defined seismicity and active volcanism in Kyushu does not continue as far as Honshu and Shikoku, the leading edge of the subducting slab is likely to have reached the upper mantle beneath the Quaternary volcanic front in SW Honshu (Fig. 1) (Nakanishi, 1980). The SVB, characterized by the occurrence of unusual HMAs, is located in the present forearc region. This is $\sim 80 \mathrm{~km}$ south of the Quaternary volcanic front and extends east-westwards for about 600 $\mathrm{km}$ along the SW Japan arc. Five major volcanic regions exist (Fig. 1), namely Shitara, Osaka, NE and SW Shikoku, and E Kyushu. New K-Ar age data for Setouchi lavas (Tatsumi et al., 2001) confirm an earlier suggestion (Tatsumi, 1983a) that the Setouchi magmatism took place within a short period of time, at $13.2 \pm 0.4 \mathrm{Ma}$. This is almost synchronous with the timing of a $40-50^{\circ}$ clockwise rotation of the arc sliver of SW Japan, and the major episode of rifting of the Japan Sea backarc basin at 1614 Ma (Otofuji et al., 1991). The southward drift of the SW Japan arc, caused by the clockwise rotation of the arc sliver, most likely resulted in the subduction of very young (15-27 Ma; Okino et al., 1994; Tamaki et al., 1999) oceanic crust of the Shikoku Basin beneath the Japan arc lithosphere (Tatsumi and Maruyama, 1989).

The samples studied here were collected from the cen- tral part of the SVB (Fig. 1). They include phenocrystpoor basalts to HMAs (sanukitoids, Tatsumi and Ishizaka, 1981). The HMAs are characterized by high $\mathrm{MgO}$ contents (ca. $7 \%$ ) and $\mathrm{MgO} / \mathrm{FeO}$ * ratios (>1). High $\mathrm{Mg}$ contents may result from processes other than the accumulation of mafic phenocrysts such as olivine (Tatsumi and Ishizaka, 1982). The reasons are twofold. First, these rocks are not porphyritic and contain $<10 \%$ phenocrysts of olivine and clinopyroxene. Second, the olivine phenocrysts have a limited Fo content of 88-90 and are in equilibrium with the bulk composition in terms of $\mathrm{Mg}$ $\mathrm{Fe}$ partitioning. The primitive nature of HMAs has been confirmed by melting experiments of a HMA (SD261). The andesite melt coexists with olivine, clinopyroxene and orthopyroxene at $1.5 \mathrm{GPa}$ and $1030^{\circ} \mathrm{C}$ and at $1.0 \mathrm{GPa}$ and $1070^{\circ} \mathrm{C}$ in the presence of $20 \%$ (water-saturated) and $7 \% \mathrm{H}_{2} \mathrm{O}$ (water-undersaturated), respectively (Tatsumi, 1982). Presence of a point of multiple saturation with lherzolitic phases (olivine, clinopyroxene and orthopyroxene) strongly suggests that the HMA is produced by partial melting of mantle peridotite. The basalt sample (SDSYB) with a high MgO content (ca. 12\%, Table 1) is also primitive and may represent the composition of mantle-derived primary magma, as inferred by both petrological and experimental studies (Tatsumi and Ishizaka, 1982; Tatsumi, 1982).

We also analyzed two Miocene basalt samples (RZ-5 and TM-0) from the NE Japan arc in order to compare the unusual Setouchi magmatism caused by subduction 
Table 2. Re-Os isotopic compositions of Setouchi HMAs and basalts

\begin{tabular}{lrrcc}
\hline & Re conc (ppt) & Os conc (ppt) & Measured ${ }^{187} \mathrm{Os} /{ }^{188} \mathrm{Os}$ & $\begin{array}{c}\text { Age-corrected } \\
187 \mathrm{Os} /{ }^{188} \mathrm{Os}\end{array}$ \\
\hline Setouchi HMA & & & & \\
SD261 & $126.4 \pm 2.3$ & $8.651 \pm 0.056$ & $0.2041 \pm 0.0026$ & 0.1875 \\
SD407 & $45.7 \pm 2.4$ & $11.529 \pm 0.054$ & $0.1718 \pm 0.0031$ & 0.1673 \\
SD411 & $29.2 \pm 0.8$ & $8.102 \pm 0.053$ & $0.2040 \pm 0.0026$ & 0.1999 \\
JA-2 & $46.7 \pm 1.6$ & $11.4 \pm 1.5$ & $0.2092 \pm 0.078$ & 0.2046 \\
Setouchi basalt & & & & \\
SDSYB & $39.0 \pm 3.3$ & $31.02 \pm 0.20$ & $0.1769 \pm 0.0006$ & 0.1755 \\
SD424 & $73.8 \pm 0.8$ & $53.72 \pm 0.58$ & $0.1556 \pm 0.0013$ & 0.1540 \\
NE Japan arc basalt & & & & \\
Ryozen (RZ-5) & $103.8 \pm 1.2$ & $148.3 \pm 6.7$ & $0.1370 \pm 0.0011$ & 0.1357 \\
Tomari (TM-0) & $96.2 \pm 1.7$ & $56.6 \pm 0.7$ & $0.1399 \pm 0.0011$ & 0.1378 \\
\hline
\end{tabular}

Errors are $2 \sigma_{m}$. Age correction for Os isotopic compositions were made using 13,22, 15 Ma as ages of the Setouchi, Ryozen, and Tomari lavas, respectively. JA-2 data are the average of four analyses (Hattori et al., 2003).

of the hot and young lithosphere with the more typical NE Japan subduction zone magmatism. These basalts were selected for their unfractionated characteristics, high $\mathrm{MgO}, \mathrm{Ni}, \mathrm{Cr}$ contents (Table 1 ) and $\mathrm{MgO} / \mathrm{FeO}^{*}$ ratios. They are thus expected to be less affected by crustal contamination and may have Os isotopic compositions that reflect the source mantle.

\section{Analytical Methods And Results}

The Re-Os analytical procedure used here has been described elsewhere (Suzuki and Tatsumi, 2001; Suzuki and Honda, 2003: Kato et al., 2005) and utilizes a Carius tube digestion (Shirey and Walker, 1995) combined with bromine-extraction of Os (Birck et al., 1997). Osmium and Re contents of the samples were determined by isotopic dilution method. Approximately $2.5 \mathrm{~g}$ of the finely pulverized rock powders were weighed, spiked with ${ }^{190} \mathrm{Os}$ and ${ }^{185} \mathrm{Re}$ and digested in inverse aqua regia in a sealed Carius tube at $220^{\circ} \mathrm{C}$ for at least 24 hours. After cooling, the tube was opened, ultrasonicated and the decomposed sample and solution were transferred into a 60-ml PFA vessel. Liquid bromine $(3 \mathrm{ml})$, concentrated $\mathrm{HNO}_{3}(3 \mathrm{ml})$ and $40 \% \mathrm{CrO}_{3}$ solution in $8 \mathrm{~N} \mathrm{HNO}_{3}(4 \mathrm{ml})$ were added. The vessel was then placed on a hotplate and heated to about $60^{\circ} \mathrm{C}$. Bromine boiling under the aqueous phase evaporated, scavenged volatile $\mathrm{OsO}_{4}$ at the top of the vessel and flowed back to the bottom. The Os-bearing liquid bromine at the bottom was then pipetted into another container with $1 \mathrm{ml}$ water. This bromine extraction step was then repeated. The water in the vial containing the pipetted bromine was discarded, and $\mathrm{HBr}(0.5 \mathrm{ml})$ was added to the liquid $\mathrm{Br}_{2}$, which was then gently evaporated. The residue including Os was further purified by micro-distillation (Roy-Barman, 1993). Rhenium was separated from the residual solution using anion exchange chromatography.

All measurements in the present study were performed in negative ion detection mode (Volkening et al., 1991, Creaser et al., 1991) on a Finnigan ${ }^{\circledR}$ MAT 262 mass spectrometer equipped with a gas leak valve and an ion counting multiplier, at Kyoto University, Beppu. From the measured oxide ratios of $\mathrm{Os}$ and $\mathrm{Re}$, atomic ratios of Os and $\mathrm{Re}$ were calculated after correcting for oxide interferences. Oxide corrections were made using ${ }^{17} \mathrm{O} /{ }^{16} \mathrm{O}$ $=0.00037$ and ${ }^{18} \mathrm{O} /{ }^{16} \mathrm{O}=0.002047$ (Nier, 1950). Instrumental mass fractionation for Os was corrected against stable ${ }^{192} \mathrm{Os} /{ }^{188} \mathrm{Os}$ ratio of 3.0827 . Total procedural blank was $\sim 7 \mathrm{pg}$ for $\mathrm{Re}$, and $\sim 2 \mathrm{pg}$ for Os with ${ }^{187} \mathrm{Os} /{ }^{188} \mathrm{Os}$ of $\sim 0.298$. Precision of ${ }^{187} \mathrm{Os} /{ }^{188} \mathrm{Os}$ measurements, based on analysis of an in-house standard over a period of several months, was better than $0.4 \%$ (2 S.D.). Standard errors ( 2 S.D.) associated with the measured ${ }^{187} \mathrm{Os} /{ }^{188} \mathrm{Os}$ are given in Table 2.

Re-Os isotopic compositions of the Setouchi primitive HMAs and basalts as well as the Ryozen and Tomari basalts are presented in Table 2. The Os isotope ratios of the volcanic rocks are age-corrected to account for growth of radiogenic ${ }^{187} \mathrm{Os}$ since time of eruption. Osmium concentrations and isotopic compositions are highly variable in Setouchi HMAs, with Os concentration ranging from 8.1 to $11.9 \mathrm{ppt}$ and age-corrected ${ }^{187} \mathrm{Os} /{ }^{188} \mathrm{Os}$ varying from 0.1718 to 0.2041 . The Setouchi basalts have lower Os isotopic compositions (0.1556-0.1769) and higher Os concentration (31.0-53.7 ppt) than those in the HMAs. On the other hand, ${ }^{187} \mathrm{Os} /{ }^{188} \mathrm{Os}$ ratios of the basalts from the NE Japan arc are 0.1370 and 0.1399 . These are considerably lower than those of Setouchi lavas and in the 
Table 3. Results of mass-balance calculations

\begin{tabular}{|c|c|c|c|c|c|c|c|}
\hline & $\mathrm{SiO}_{2}$ & $\mathrm{Al}_{2} \mathrm{O}_{3}$ & $\mathrm{FeO} *$ & $\mathrm{MgO}$ & $\mathrm{CaO}$ & $\mathrm{Na}_{2} \mathrm{O}$ & Fraction \\
\hline \multicolumn{8}{|l|}{ granite } \\
\hline basalt & 51.1 & 15.9 & 9.1 & 12.0 & 9.2 & 2.7 & 68.5 \\
\hline granite & 74.7 & 15.8 & 2.3 & 0.4 & 3.3 & 3.5 & 33.3 \\
\hline olivine & 40.0 & 0.0 & 10.0 & 50.0 & 0.0 & 0.0 & -1.7 \\
\hline clinopyroxene & 52.5 & 5.0 & 3.0 & 15.5 & 23.0 & 1.0 & -0.1 \\
\hline HMA & 59.1 & 16.4 & 6.5 & 7.6 & 7.4 & 3.0 & \\
\hline calculated & 59.1 & 16.2 & 6.8 & 7.5 & 7.4 & 3.0 & $R^{2}=0.183$ \\
\hline \multicolumn{8}{|l|}{ gneiss } \\
\hline basalt & 51.1 & 15.9 & 9.1 & 12.0 & 9.2 & 2.7 & 39.9 \\
\hline gneiss & 66.8 & 17.9 & 5.4 & 0.7 & 5.3 & 3.9 & 53.0 \\
\hline olivine & 40.0 & 0.0 & 10.0 & 50.0 & 0.0 & 0.0 & 3.3 \\
\hline clinopyroxene & 52.5 & 5.0 & 3.0 & 15.5 & 23.0 & 1.0 & 3.7 \\
\hline HMA & 59.1 & 16.4 & 6.5 & 7.6 & 7.4 & 3.0 & \\
\hline calculated & 59.1 & 16.0 & 6.9 & 7.4 & 7.4 & 3.2 & $R^{2}=0.380$ \\
\hline \multicolumn{8}{|l|}{ gabbro } \\
\hline basalt & 51.1 & 15.9 & 9.1 & 12.0 & 9.2 & 2.7 & -184.3 \\
\hline gabbro & 55.9 & 18.7 & 8.9 & 4.1 & 8.9 & 3.5 & 234.7 \\
\hline olivine & 40.0 & 0.0 & 10.0 & 50.0 & 0.0 & 0.0 & 34.2 \\
\hline clinopyroxene & 52.5 & 5.0 & 3.0 & 15.5 & 23.0 & 1.0 & 15.4 \\
\hline HMA & 59.1 & 16.4 & 6.5 & 7.6 & 7.4 & 3.0 & \\
\hline calculated & 58.8 & 15.3 & 8.0 & 7.0 & 7.4 & 3.5 & $R^{2}=4.05$ \\
\hline \multicolumn{8}{|c|}{ inferred lower crust } \\
\hline basalt & 51.1 & 15.9 & 9.1 & 12.0 & 9.2 & 2.7 & -301.2 \\
\hline lower crust & 54.3 & 17.2 & 8.7 & 7.4 & 9.8 & 2.7 & 371.5 \\
\hline olivine & 40.0 & 0.0 & 10.0 & 50.0 & 0.0 & 0.0 & 33.3 \\
\hline clinopyroxene & 52.5 & 5.0 & 3.0 & 15.5 & 23.0 & 1.0 & -3.6 \\
\hline HMA & 59.1 & 16.4 & 6.5 & 7.6 & 7.4 & 3.0 & \\
\hline calculated & 59.1 & 15.9 & 8.2 & 7.3 & 7.7 & 1.9 & $R^{2}=4.57$ \\
\hline
\end{tabular}

Major elements data for granite, gneiss and gabbro are from Tatsumi et al. (2002); Data for average lower crust are from Rudnick and Fountain (1995); Data for basalt are from Shimoda et al. (1998).

range measured for arc and back-arc ultramafic xenoliths from Ichinomegata, Japan (Brandon et al., 1996), Simcoe, USA (Brandon et al., 1996, 1999), Lihir Island, Papua New Guinea (McInnes et al., 1999) and Kamchatka (Widom et al., 2003).

\section{DiscuSSION}

\section{Shalow-level crustal assmilation}

One possible mechanism for producing the ${ }^{187} \mathrm{Os} /{ }^{188} \mathrm{Os}$ variation observed for the Setouchi rocks is greater degrees of shallow-level crustal assimilation in HMAs than basalts, as crustal material generally possesses higher ${ }^{187} \mathrm{Os} /{ }^{188} \mathrm{Os}$ (e.g., upper crust; $1.0-1.4$, PeuckerEhrenbrink and Jahn, 2001; Hattori et al., 2003). Ruiz et al. (1998) showed that crustal contamination can produce high ${ }^{187} \mathrm{Os} /{ }^{188} \mathrm{Os}$ ratios in arc magmas, on the basis of a positive correlation between Os isotope ratios and crustal thickness in the Chilean Southern Volcanic Zone. Lassiter and Luhr (2001) suggested that an inverse correlation of
${ }^{187} \mathrm{Os} /{ }^{188} \mathrm{Os}$ ratios with Os abundance in the Mexican arc lavas can also be explained by assimilation of lower crustal material, with ${ }^{187} \mathrm{Os} /{ }^{188} \mathrm{Os}$ ranging from 0.5 to 2.2 and Os concentrations between 20 and 160 ppt, during fractional crystallization. Hart et al. (2002) also interpreted the radiogenic Os isotope compositions of calcalkaline volcanic rocks from the Lassen volcanic region of the Cascade arc to reflect significant interaction with lower crustal material.

The petrological characteristics of the Setouchi HMAs (Tatsumi, 1982; Tatsumi and Ishizaka, 1982; Tatsumi et al., 2002), such as limited $\mathrm{Mg \#}(=100 \times \mathrm{Mg} /(\mathrm{Mg}+\mathrm{Fe})$ ) and high $\mathrm{NiO}$ contents in olivine phenocrysts (88-90, 0.40 $\mathrm{wt} \%$, respectively), high $\mathrm{Cr} /\left(\mathrm{Cr}+\mathrm{Al}+\mathrm{Fe}^{3+}\right)$ in chromite inclusions ( 0.65$)$ may imply lesser role of crustal contamination. However, it is still important to assess the likelihood of such a process using the geochemical data available.

In order to evaluate the effect of AFC processes, four crustal components were examined (Table 3 ). Those were 
granite and gneiss, from basement rocks on Shodo-Shima Island (Tatsumi et al., 2002), representative of the upper crust. A gabbro composition from Shodo-Shima Island (Tatsumi et al., 2002) and an average lower crust composition (Rudnick and Fountain, 1995) were also used as representative of the lower crust. Because olivine and clinopyroxene are present as phenocryst phases in both the basalts and the HMAs, a simple least-square mixing calculation using the compositions of basalt, HMA, the crustal materials, and phenocryst phases may provide reasonable estimates for degrees of assimilation and crystallization. Although partial, rather than bulk assimilation may be the case during such a process, it is difficult to estimate the fraction of melting phases and also lack of fundamental data of Os for calculation such as partition coefficients into the rock constituting minerals and mobilities from the subducted material into fluid hinders further calculation based on partial assimilation. The present modeling thus assumes the assimilation of bulk crustal rocks. The results of mixing calculations (Table 4) indicate that an HMA magma composition can be reproduced from a parental basalt magma through crustal AFC processes by assimilating granitic upper crust with crystallizing olivine and clinopyroxene. It seems unlikely that only a small degree of crystallization of phenocrysts $(<2 \mathrm{wt} \%)$ would be the consequence of a large degree of assimilation of granite $(>30 \mathrm{wt} \%)$ does not seem likely. Further examination, however, based on trace element and isotopic compositions is obviously required. The modeling results with the other three crustal components are not appropriate for the following reasons: (1) a parental basalt magma requires olivine and clinopyroxene accumulation which is not observed in petrography of the HMA and (2) the sum of squares of residuals $\left(R^{2}\right)$ obtained for the mixing calculations is far beyond the acceptable limit ( 1.5; Mann, 1983).

The results of trace element and isotope model calculations for granite AFC are listed in Table 4. Potassium, $\mathrm{Ba}, \mathrm{Rb}, \mathrm{Zr}$ and isotopic compositions for $\mathrm{Sr}, \mathrm{Pb}$ and $\mathrm{Os}$ yield results inconsistent with the data observed for Setouchi volcanic rocks. This suggests that the HMA magmas were not produced from the basalt magmas through crustal AFC processes. Alves et al. (2002) reported that Os initial isotope ratios are positively and linearly correlated in ${ }^{187} \mathrm{Os} /{ }^{188} \mathrm{Os}$ ratio vs. $1 /[\mathrm{Os}]$ space in arc lavas from 10 different subduction zones including Lesser Antilles, Java and Izu Bonin. They claimed that it is hard to reconcile a single shallow-level process of crustal assimilation as being responsible for these correlations because of the variability of the crustal components. Alternatively, they introduced variability of subducted materials that may account for the origin of the linear arrays found in arc level or volcano level variations. Our crustal AFC calculation results also suggest
Table 4. Results of mixing calculations

\begin{tabular}{lcccc}
\hline & basalt & granite & calculated & HMA \\
\hline inconsistent & & & & \\
$\mathrm{K}_{2} \mathrm{O}(\mathrm{wt} \%)$ & 1.20 & 2.95 & 1.78 & 2.25 \\
$\mathrm{Ba}(\mathrm{ppm})$ & 219 & 1052 & 497 & 195 \\
$\mathrm{Rb}(\mathrm{ppm})$ & 33 & 83 & 50 & 114 \\
$\mathrm{Zr}(\mathrm{ppm})$ & 99 & 176 & 125 & 80 \\
$\mathrm{Os}(\mathrm{ppt})$ & 31 & 30 & 31 & 8.65 \\
$\mathrm{Re}(\mathrm{ppt})$ & 39 & 200 & 93 & 126 \\
${ }^{87} \mathrm{Sr} /{ }^{86} \mathrm{Sr}$ & 0.7044 & 0.7079 & 0.7055 & 0.7049 \\
${ }^{206} \mathrm{~Pb} /{ }^{204} \mathrm{~Pb}$ & 18.32 & 18.54 & 18.42 & 18.37 \\
${ }^{208} \mathrm{~Pb} /{ }^{20} \mathrm{~Pb}$ & 38.47 & 38.83 & 38.64 & 38.56 \\
${ }^{187} \mathrm{Os} /{ }^{186} \mathrm{Os}$ & 0.1755 & 1.0000 & 0.6301 & 0.1875 \\
& & & & \\
$\mathrm{consistent}$ & & & & \\
$\mathrm{P}_{2} \mathrm{O}_{5}$ & 0.27 & 0.07 & 0.20 & 0.17 \\
$\mathrm{Nb}(\mathrm{ppm})$ & 4 & 7 & 5 & 5 \\
$\mathrm{Ni}(\mathrm{ppm})$ & 207 & 0 & 138 & 148 \\
$\mathrm{Sr}(\mathrm{ppm})$ & 277 & 257 & 270 & 267 \\
$\mathrm{Nd}(\mathrm{ppm})$ & 14 & 23 & 17 & 16 \\
$\mathrm{~Pb}(\mathrm{ppm})$ & 8 & 15 & 10 & 17 \\
$\mathrm{Th}(\mathrm{ppm})$ & 4 & 12 & 7 & 5 \\
$\mathrm{Y}(\mathrm{ppm})$ & 18 & 16 & 17 & 15 \\
${ }^{143} \mathrm{Nd} /{ }^{144} \mathrm{Nd}$ & 0.5127 & 0.5124 & 0.5126 & 0.5127 \\
${ }^{207} \mathrm{~Pb} /{ }^{204} \mathrm{~Pb}$ & 15.57 & 15.61 & 15.59 & 15.58 \\
\hline
\end{tabular}

Data sources are from Tatsumi et al. (2002), Shimoda et al. (1998), and this study.

derivation of the isotopic variation is likely to be caused by mantle processes rather than crustal processes.

\section{Slab-fluids or slab-melts?}

The alternative possible cause of the elevated Os isotopic compositions of the Setouchi basalts and HMAs (Table 2) is an input of radiogenic Os from a slab-component. It is widely accepted that the chemistry of the mantle wedge overlying a subducted slab varies considerably compared to other portions of the upper mantle. This can be caused by metasomatic overprinting by subduction components. Elevated Os isotopic ratios relative to primitive upper mantle can be found in peridotite xenoliths from arc and back-arc environments (Brandon et al., 1996, 1999; McInnes et al., 1999; Widom et al., 2003), indicating that at least a part of the wedge mantle is metasomatized by slab-derived radiogenic Os. Identification of such subduction components (slab-fluid or slab-melt) has thus been a principal target of petrological and geochemical studies of subduction zone magmatism.

In order to evaluate the signature of the slab-derived component, mixing calculations between wedge mantle and hypothetical slab-melts and fluids have been conducted based on Os vs. $\mathrm{Sr}, \mathrm{Nd}$ and $\mathrm{Pb}$ isotopes. Tatsumi and Hanyu (2003) presented sophisticated geochemical models to account for various processes; mixing between altered oceanic crust and sediments melts/fluids to pro- 

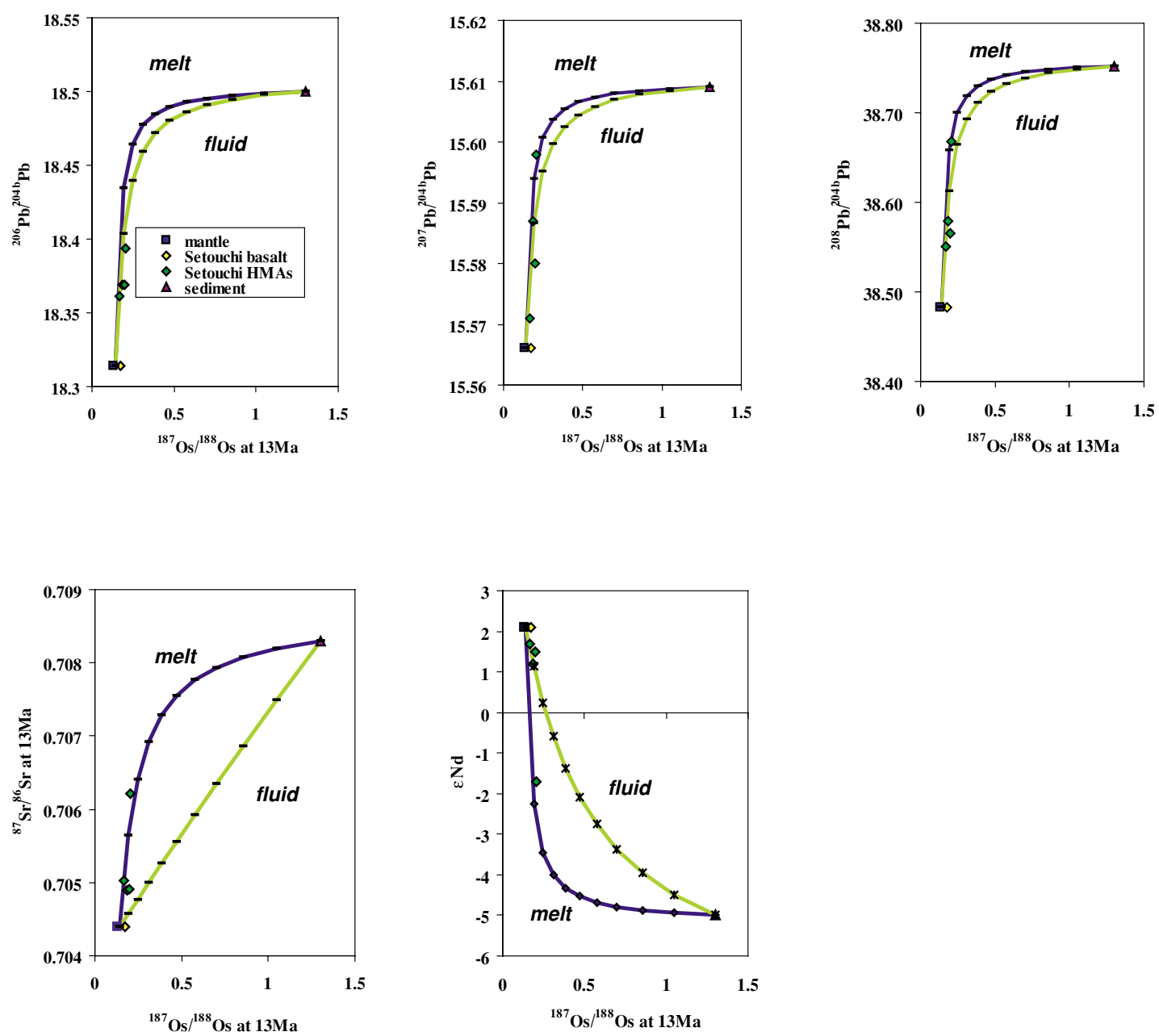

Fig. 2. Results of mixing calculations. For chemical compositions of the assumed end-members, see text. The Sr, Nd and Pb isotopic compositions of the inferred mantle used in the calculations are the data for the primitive Setouchi basalt, SDSYB (Table 1). The ${ }^{87} \mathrm{Sr} /{ }^{86} \mathrm{Sr}, \varepsilon_{N d}$ and ${ }^{206} \mathrm{~Pb} /{ }^{204} \mathrm{~Pb},{ }^{207} \mathrm{~Pb} /{ }^{204} \mathrm{~Pb},{ }^{208} \mathrm{~Pb} /{ }^{204} \mathrm{~Pb}$ isotopic compositions of the sediment are 0.70829, -5.0 , 18.500, 15.609 and 38.752, respectively. These are the data obtained for terrigenous sediment from the Nankai Trough (Fig. 1) (Shimoda et al., 1998). The isotopic compositions of the Setouchi HMAs can explained by the addition of several percentages of sediment melt to an original mantle, but not by addition of fluid.

duce the metasomatic agent, and interaction of this melts/ fluids and original wedge mantle. We, however, prefer to employ the simple mixing calculation used by Shimoda et al. (1998). This is because we are currently lacking sufficient fundamental data on Os behavior during various geological processes, such as its distribution coefficients during partial melting and dehydration processes. Our calculations employ the following assumptions proposed by Shimoda et al. (1998) for the chemical compositions of $\mathrm{Sr}, \mathrm{Nd}$ and $\mathrm{Pb}$ end-members: (1) total melting of terrigenous sediments $(\mathrm{Sr}, \mathrm{Nd}$ and $\mathrm{Pb}$ abundance of $180,30,20 \mathrm{ppm}$, respectively), (2) the chemical composition of the fluid was based on the experimental results of Aizawa et al. (1999) ( $\mathrm{Sr}, \mathrm{Nd}$ and $\mathrm{Pb}$ abundance of 18 , $3,10 \mathrm{ppm}$, respectively), and (3) the composition of the inferred mantle wedge was calculated using chemical compositions of the primitive basalt, SYSYB, by assuming appropriate partition coefficients (Green, 1994), and $15 \%$ batch partial melting of lherzolite with $55 \%$ olivine, $30 \%$ orthopyroxene and $15 \%$ clinopyroxene (Shimoda et al., 1998). We assume that the mantle possesses a ${ }^{187} \mathrm{Os} /$ ${ }^{188} \mathrm{Os}$ of 0.14 and an Os concentration of $2.5 \mathrm{ppb}$, and that slab-derived components, both fluid and melt have similar Os isotopic compositions of average upper continental crust $\left({ }^{187} \mathrm{Os} /{ }^{188} \mathrm{Os}=1.3\right.$; Peucker-Ehrenbrink and Jahn, 2001; Hattori et al., 2003). For the Os contents of both melt and fluid from sediment, we used a ratio of Os concentration between mantle and slab-components of 2.5:1, following the assumptions of Brandon et al. (1996, 1999). The subducted oceanic crust is likely to contrib- 
ute little to the melt or fluid generation. One of the reasons is that the Os concentration of MORB $(<5$ ppt, e.g., Escrig et al., 2005) is much lower than the typical marine sediments (30-1000 ppt, e.g., Peucker-Ehrenbrink et al., 1995: Cohen et al., 1999; Dalai et al., 2005). The other reason is that the subducted Shikoku Basin is too young (15-27 Ma; Okino et al., 1994; Tamaki et al., 1999) to have the elevated Os isotopic composition. The age of the Shikoku Basin lithosphere was 2-14 Ma when the SVB was formed at $13 \mathrm{Ma}$. The oceanic crust with typical ${ }^{187} \mathrm{Re} /{ }^{188} \mathrm{Os}$ ratio of 1000 (e.g., Escrig et al., 2005) has ${ }^{187} \mathrm{Os} /{ }^{188} \mathrm{Os}$ of $0.16-0.36$ at $2-14 \mathrm{Ma}$. The oceanic crust with such low ${ }^{187} \mathrm{Os} /{ }^{188} \mathrm{Os}$ and low Os concentration is less likely to play an important role in producing the Os concentration and isotopic compositions of the Setouchi HMAs.

The results of the mixing calculations are shown in Fig. 2. The addition of several percent of a sediment-derived melt reproduces the $\mathrm{Os}-\mathrm{Sr}-\mathrm{Nd}-\mathrm{Pb}$ isotope compositions of the HMA magma source. Despite the obvious success in reproducing the $\mathrm{Os}-\mathrm{Pb}$ isotope relationship, the sediment-derived fluid is an unlikely end-member, as mixing between mantle and sediment-derived fluid cannot account for their Os vs. Sr or $\mathrm{Nd}$ isotope data. Therefore, a slab-derived melt may have played a major role in the Os-Sr-Nd-Pb characteristics of Setouchi HMAs.

We assumed the assimilated mantle possesses a ${ }^{187} \mathrm{Os} /$ ${ }^{188}$ Os ratio of 0.14 , which is higher than that of hypothetical primitive upper mantle $(0.1296$, Meisel et al., 2001), but is in the range of peridotite xenoliths from arc and back-arc settings. Though Chesley et al. (2004) suggested metasomatism of the upper mantle by slab-derived material does not elevate Os isotopic compositions of large-scale mantle, their calculation does not necessarily rule out the likely elevation of wedge mantle Os isotopic compositions on a localized scale. Lassiter and Luhr (2001) proposed that Os isotopic and abundance signatures of Mexican volcanic lavas were caused by upper crustal assimilation, assuming a ${ }^{187} \mathrm{Os} /{ }^{188} \mathrm{Os}$ ratio of 0.135 for the initial mantle melt. This Os isotopic ratio is still higher than that of typical upper mantle, reflecting the input of slab-derived materials (Lassiter and Luhr, 2001). Meisel et al. (2001) also mentioned the possible contamination of mantle wedge by a crustal component resulting in higher ${ }^{187} \mathrm{Os} /{ }^{188} \mathrm{Os}$ ratios in the mantle wedge than in typical upper mantle. Moreover, it is also possible that mantle lithosphere beneath SW Japan has been affected by a slab component, since the arc has been subjected to subduction magmatism since the Cretaceous (e.g., Kagami et al., 1992). We have little knowledge about the mantle lithosphere beneath the arc; however, Os isotope ratios reported in N-NE China and NE Japan (Ichinomegata) range from 0.117 to 0.133 (Wu et al., 2003; Gao et al., 2002; Brandon et al., 1996). Although petrographically the most primitive basalt, SDSYB (c.f., Table 1, 2, Tatsumi, 1982; Tatsumi and Ishizaka, 1982) should possess Os isotopic compositions similar to that of primitive upper mantle $(\sim 0.13)$, this basalt yields a high ${ }^{187} \mathrm{Os} /{ }^{188} \mathrm{Os}$ ratio of 0.175 . This result indicates the primitive basalt SDSYB also contains slab-derived components, as suggested by Shimoda et al. (1998) and Tatsumi (2001).

The Os isotope ratios of the primitive basalts from NE Japan (0.136-0.138) are within the range of Os isotopic compositions of arc peridotites (0.120-0.156, Brandon et al., 1996, 1999; McInnes et al., 1999; Becker et al., 2001; Widom et al., 2003) and are much lower than the Setouchi HMAs and basalts (0.167-0.204). Though we cannot reach a conclusive interpretation because of the severely limited number of Os isotopic data sets, the difference in the Os isotope ratios may reflect differences in tectonic settings. Widom et al. (2003) reported the less radiogenic ${ }^{187} \mathrm{Os} /{ }^{188} \mathrm{Os}$ ratios of harzburgites from Avachinsky which is associated with relatively cold, old ( 100-175 Ma) subducting slabs. Relatively more radiogenic Os are from peridotite xenoliths from the Kamchatka volcanoes associated with hot and young $(\sim 25$ Ma) slab. The latter case is characterized by adakitic slab melts. They suggested multistage metasomatism resulting from the interaction of the mantle wedge with a variety of slab-derived fluids and melts. They suggest the presence of hydrous slab-fluid metasomatism associated with cold and old oceanic crust and silicic slab-melt metasomatism associated with subduction of young oceanic crust. Our SBV and NE Japan results compare well with the result of Widom et al. (2003). The SVB volcanism involves the subduction of young (2-14 Ma) slab and the volcanic rocks yield relatively radiogenic Os isotopic compositions, which is likely to be caused by contemporaneous slab-derived melts. On the other hand, the basalts from NE Japan with less radiogenic Os isotopic compositions are possibly associated with slab-derived fluid.

\section{Conclusions}

Primitive Setouchi high-Mg andesites and basalts possess elevated Os isotopic signatures. Geochemical modeling suggests that the HMAs are not produced by AFC processes within the crust, but are mantle-derived. Osmium vs. $\mathrm{Sr}, \mathrm{Nd}$ and $\mathrm{Pb}$ isotopic trends can be explained by melting of subducting sediments and subsequent meltmantle interaction. In contrast, the Os isotopic ratios of primitive basalts from NE Japan, yielding lower Os isotopic ratios, are within the range of arc peridotites, and may reflect a different mechanism of Os transport (slabderived fluids?) in this region where an older, cooler slab is being subducted. 
Acknowledgments-We are very much indebted to Monica Handler for her careful review of an earlier version of our manuscript. We also thank Kyoko Abe for assistance with sample preparation and chemical analyses. Constructive comments by Jun-ichi Kimura, Takafumi Hirata and an anonymous reviewer significantly improved our manuscript. This work was supported in part by Sasakawa Scientific Research Grant from the Japan Science Society, the REIMEI Research Resources of Japan Atomic Energy Research Institute and a Grant-in Aid (\# 12740304 and 14703002) from the Monbusho and JSPS to KS.

\section{REFERENCES}

Aizawa, Y., Tatsumi, Y. and Yamada, H. (1999) Element transport during dehydration of subducting sediments: Implication for arc and ocean island magmatism. Island Arc 8, 3846.

Alves, S., Schiano, P. and Allegre, C. J. (1999) Rhenium-osmium isotopic investigation of Java subduction zone lavas. Earth Planet. Sci. Lett. 168, 65-77.

Alves, S., Schiano, P., Capmas, F. and Allegre, C. J. (2002) Osmium isotope binary mixing arrays in arc volcanism. Earth Planet. Sci. Lett. 198, 355-369.

Becker, H. (2000) Re-Os fractionation in eclogites and blueschists and the implications for recycling of oceanic crust into the mantle. Earth Planet. Sci. Lett. 177, 287-300.

Becker, H., Shirey, S. B . and Carlson, R.W. (2001) Effects of melt percolation on the Re-Os systematics of peridotites from a Paleozoic convergent plate margin. Earth Planet. Sci. Lett. 188, 107-121.

Birck, J. L., Roy-Barman, M. and Capmas, F. (1997) Re-Os isotopic measurements at the femtomole level in natural samples. Geost. Newslett. 21, 19-27.

Borg, L. E., Brandon, A. D., Clynne, M. A. and Walker, R. J. (2000) Re-Os isotopic systematics of primitive lavas from the Lassen region of the Cascade arc, California. Earth Planet. Sci. Lett. 177, 301-317.

Brandon, A. D., Creaser, R. A., Shirey, S. B. and Carlson, R. W. (1996) Osmium recycling in subduction zones. Science 272, 861-864.

Brandon, A. D., Becker, H., Carlson, R. W. and Shirey, S. B. (1999) Isotopic constraints on time scales and mechanisms of slab material transport in the mantle wedge: evidence from the Simcoe mantle xenoliths, Washington, USA. Chem. Geol. 160, 387-407.

Brophy, J. G. and Marsh, B. D. (1986) On the origin of high alumina arc basalt and the mechanics of melt extraction. $J$. Petrol. 27, 763-789.

Chesley, J., Righter, K. and Ruiz, J. (2004) Large-scale mantle metasomatism: a Re-Os perspective. Earth Planet. Sci. Lett. 219, 49-60.

Coats, R. R. (1962) Magma type and crystal structure in the Aleutian arc. Am. Geophys. Union Monogr. Vol. 6, 92-109, AGU, Washington, D.C.

Cohen, A. S., Coe, A. L., Bartlett, J. M. and Hawkesworth, C. J. (1999) Precise Re Os ages of organic-rich mudrocks and the Os isotope composition of Jurassic seawater. Earth Planet. Sci. Lett. 167, 159-173.

Crawford, A. J., Falloon, T. J. and Green, D. H. (1989) Classi- fication petrogenesis and tectonic setting of boninites. Boninites and Related Rocks (Crawford, A. J., eds.), 1-49, Unwin Hyman, London.

Creaser, R. A., Papanastassiou, D. A. and Wasserburg, G. J. (1991) Negative thermal ion mass spectrometry of osmium, rhenium, and iridium. Geochim. Cosmochim. Acta 55, 397401.

Dalai, T. K., Suzuki, K., Minagawa, M. and Nozaki, Y. (2005) Os isotopic record of the Japan Sea sediments over the last glacial-interglacial climate cycle. Chem. Geol. 220, 303314.

Defant, M. J. and Drummond, M. S. (1990) Derivation of some modern arc magmas by melting of young subducted lithosphere. Nature 347, 662-665.

Drummond, M. S. and Defant, M. J. (1990) A model for trodhjemite-tonalite-dacite genesis and crustal growth through slab melting: Archean to modern comparisons. $J$. Geophys. Res. 95, 21503-21521.

Escrig, S., Schiano, P., Schilling, J.-G. and Allegre, C. (2005) Rhenium-osmium isotope systematics in MORB from the Southern Mid-Atlantic Ridge (408-508 S). Earth Planet. Sci. Lett. 235, 528-548.

Esser, B. and Turekian, K. K. (1993) The osmium isotopic composition of the continental crust. Geochim. Cosmochim. Acta 57, 3093-3104.

Furukawa, Y. and Tatsumi Y. (1999) Melting of a subducting slab and production of high-Mg andesite magmas: Unusual magmatism in SW Japan at 13-15 Ma. Geophys. Res. Lett. 26, 2271-2274.

Gao, S., Rudnick, R. L., Carlson, R. W., McDonough, W. F. and Liu Y.-S. (2002) Re-Os evidence for replacement of ancient mantle lithosphere beneath the North China craton. Earth Planet. Sci. Lett. 198, 307-322.

Green, T. H. (1994) Experimental studies of trace-element partitioning applicable to igneous petrogenesis-Sedona 16 years later. Chem. Geol. 117, 1-36.

Jenner, G. A. (1981) Geochemistry of high-Mg andesites from Cape Vogel, Papua New Guinea. Chem. Geol. 33, 307-332.

Hanyu, T., Tatsumi, Y. and Nakai, S. (2002) A contribution of slab-melts to the formation of high-Mg andesite magmas: Hf isotopic evidence from SW Japan. Geophys. Res. Lett. 29, 2051, doi:10.1029/2002GL015856.

Hart, G. L., Johnson, C. M., Shirey, S. B. and Clynne, M. A. (2002) Osmium isotope constraints on lower crustal recycling and pluton preservation at Lassen Volcanic Center, CA. Earth Planet. Sci. Lett. 199, 269-285.

Hattori, Y., Suzuki, K., Honda, M. and Shimizu, H. (2003) ReOs isotope systematics of the Taklimakan Desert sands, moraines and river sediments around the Taklimakan Desert, and of Tibetan soils. Geochim. Cosmochim. Acta 67, 11951205.

Kagami, H., Iizumi, S., Tainosho, Y. and Owada, M. (1992) Spatial variations of $\mathrm{Sr}$ and $\mathrm{Nd}$ isotope ratios of Cretaceaous-Paleogene granitoid rocks, Southwest Japan Arc. Contrib. Mineral. Petrol. 112, 165-177.

Kaneoka, I., Takigami, Y., Takaoka, N., Yamashita, S. and Tamaki, K. (1992). ${ }^{40} \mathrm{Ar}-{ }^{39} \mathrm{Ar}$ analysis of volcanic rocks recovered from the Japan Sea floor; constraints on the age of formation of the Japan Sea. Proc. Ocean Drill. Proj., Sci. 
Res. 127/128, 819-836.

Kato, Y., Fujinaga, K. and Suzuki, K. (2005) Major, trace, and rare earth element geochemistry and Os isotopic composition of metalliferous umbers from the late Cretaceous Japanese accretionary complex. Geochem. Geophys. Geosyst. 6, Q07004, DOI 10.1029/2005GC000920.

Kay, R. W. (1978) Aleutian magnesian andesites: melts from subducted Pacific ocean crust. J. Volcanol. Geotherm. Res. 7, 117-182.

Keleman, P. B. (1995) Genesis of high Mg\# andesites and the continental crust. Contrib. Mineral. Petrol. 120, 1-19.

Kimura, J.-I., Kunikiyo, T., Osaka, I., Nagao, T., Yamauchi, S., Kakubuchi, S., Okada, S., Fujibayashi, N., Okada, R., Murakami, H., Kusano, T., Umeda, K., Hayashi, S., Ishimaru, T., Ninimiya, A. and Tanase, A. (2003) Late Cenozoic volcanic activity in the Chugoku area, Southwest Japan arc: Activity during back-arc basin opening and reinitiation of subduction. Island Arc 12, 22-45.

Kuroda, N., Shiraki, K. and Urano, H. (1978) Boninite as a possible calc-alkalic primary magma. Bull. Volcanol. 41, 563-575.

Kushiro, I. (1969) The system forsterite-diopside-silica with and without water at high pressures. Amer. J. Sci. 267-A, 269-294.

Kushiro, I. (1972) Effect of water on the composition of magmas formed at high pressures. J. Petrol. 13, 311-334.

Lassiter, J. C. and Luhr, J. F. (2001) Osmium abundance and isotope variations in mafic Mexican volcanic rocks: Evidence for crustal contamination and constraints on the geochemical behavior of osmium during partial melting and fractional crystallization. Geochem. Geophys. Geosyst. 2, $2000 \mathrm{GC} 000116$.

Mann, A. C. (1983) Trace element geochemistry of high alumina basalt-andesite-dacite-rhyodacite lavas of the Main Volcanic Series of Santorini Volcano, Greece. Contrib. Mineral. Petrol. 84, 43-57.

Martin, H. (1987) Petrogenesis of Archaean trondhjemites, tonalites and granodiorites from eastern Finland: major and trace element geochemistry. J. Petrol. 28, 921-953.

McInnes, B. I. A., McBride, J. S., Evans, N. J., Lambert, D. D. and Andrew, A. S. (1999) Osmium isotope constraints on ore metal recycling in subduction zones. Science $\mathbf{2 8 6}, 512$ 516.

Meisel, T., Walker, R. J., Irving, A. J. and Lorand, J.-P. (2001) Osmium isotopic compositions of mantle xenoliths: A global perspective. Geochim. Cosmochim. Acta 65, 1311-1323.

Nakanishi, I. (1980) Precursors to ScS phases and dipping interface in the upper mantle beneath southwestern Japan. Tectonophys. 69, 1-35.

Nicholls, I. A. and Ringwood, A. E. (1973) Effect of water on olivine stability in tholeiites and the production of silica saturated magmas in the island arc environment. J. Geol. 81, 285-300.

Nier, A. O. A. (1950) Redetermination of the relative abundances of the isotopes of carbon, nitrogen, oxygen, argon and potassium. Phys. Rev. B77, 789-793.

Okino, K., Shimakawa, Y. and Nagaoka, S. (1994) Evolution of the Shikoku Basin. J. Geomag. Geoelectr. 46, 463-479.

Otofuji, Y., Itaya, T. and Matsuda, T. (1991) Rapid rotation of southwest Japan: Paleomagnetism and K-Ar ages of Miocene volcanic rocks of Southwest Japan. Geophys. J. Int. 105, 397-405.

Peacock, S. M. (1990) Numerical simulation of metamorphic pressure-temperature-time paths and fluid production in subducting slabs. Tectonics 9, 1197-1211.

Peacock, S. M. and Wang, K. (1999) Seismic consequences of warm versus cool subduction metamorphism: Examples from Southwest and Northeast Japan. Science 286, 937-939.

Pearce, J. A., van der Laan, S. R., Arculus, R. J., Murton, B. J., Ishi, T., Peaate, D. W. and Parkinson, J. J. (1992) Boninite and harzburgite from Leg 125 (Bonin-Mariana forearc): a case study of magma genesis during the initial stages of subduction. Proc. Ocean Drill. Pro., Sci. Res. 125, Ocean Drill. Prog., 623-659.

Peucker-Ehrenbrink B. and Jahn B.-M. (2001) Rhenium-osmium isotope systematics and platinum group element concentrations: Loess and the upper continental crust. Geochem. Geophys. Geosyst. 2, Paper 2001GC000172.

Peucker-Ehrenbrink, B., Ravizza, G. and Hofmann, A. W. (1995) The marine ${ }^{187} \mathrm{Os} /{ }^{188} \mathrm{Os}$ record of the past 80 million years. Earth Planet. Sci. Lett. 130, 155-167.

Ravizza, G. (1993) Variations in the ${ }^{187} \mathrm{Os} /{ }^{188} \mathrm{Os}$ of seawater over the past 28 million years as inferred from metalliferous carbonates. Earth Planet. Sci. Lett. 188, 335-348.

Roy-Barman, M. (1993) Mesure du rapport ${ }^{187} \mathrm{Os} /{ }^{188} \mathrm{Os}$ dans les basaltes et les peridotites: contribution a la systematique ${ }^{187} \mathrm{Re}-{ }^{188}$ Os dans le manteau. Ph.D. Thesis, Universite de Paris, France.

Rudnick, R. L. and Fountain, D. M. (1995) Nature and composition of the continental crust: a lower crustal perspective. Rev. Geophys. 33, 267-309.

Ruiz, J., Hildreth, W. and Chesley, J. (1998) Crustal contributions to arc magma genesis: Os isotopic evidence from the Southern Volcanic Zone of Chile. EOS Trans. American Geophys. Union 79, Fall Meet Suppl. F969.

Sato, H. (1977) Nickel content of basaltic magma: identification of primary magmas and measure of the degree of olivine fractionation. Lithos 10, 113-120.

Sekine, T. and Wyllie, P. J. (1982) Phase relationships in the system $\mathrm{KAlSiO}_{4}-\mathrm{Mg}_{2} \mathrm{SiO}_{4}-\mathrm{SiO}_{2}-\mathrm{H}_{2} \mathrm{O}$ as a model for hybridization between hydrous siliceous melts and peridotite. Contrib. Mineral. Petrol. 79, 368-374.

Shimoda, G., Tatsumi, Y., Nohda, S., Ishizaka, K. and Jahn, B. M. (1998) Setouchi high-Mg andesites revisited: geochemical evidence for melting of subducting sediments. Earth Planet. Sci. Lett. 160, 479-492.

Shirey, S. B. and Walker, R. J. (1995) Carius tube digestion for low-blank rhenium-osmium analysis. Anal. Chem. 67, 21362141.

Suzuki, K. and Honda, M. (2003) Analytical procedure of osmium and rhenium isotopes. Frontier Research on Earth Evolution, Volume 1, IFREE REPORT for 2001-2002, 379381.

Suzuki, K. and Tatsumi, Y. (2001) Osmium concentrations and isotopic compositions of GSJ standard rocks, JB-1a, JA-2 and JP-1. Geochem. J. 35, 207-210.

Suzuki, K., Aizawa, Y. and Tatsumi, Y. (2003) Osmium transport during dehydration processes in the subducted slab: 
Experiments and implications for the Os isotopic compositions of arc magmas. Frontier Research on Earth Evolution, Volume 1, IFREE REPORT for 2001-2002, 107-110.

Tada, R. and Tamaki, K. (1992) Scientific results of ODP Japan Sea Legs, and their implication for stratigraphy. J. Jpn. Assoc. Petrol. Tech. 57, 103-111.

Tamaki, K., Suyehiro, K., Allan, J., Ingle, J. C. J. and Pisciotto, K. A. (1992) Tectonic synthesis and implications of Japan Sea ODP drilling. Proc. Ocean Drill. Proj., Sci. Res. 127/ 128, 1333-1348.

Tamaki, K., Hsieh, K. Y., Tamura, C., Yamaashi, T. and Sasaki, T. (1999) High resolution reconstruction of the spreading tectonics of the Shikoku Basin in the Philippine Sea. Eos, Transactions, Am. Geophys. Union 80 Suppl., 1040.

Tatsumi, Y. (1981) Melting experiments on a high magnesian andesite. Earth Planet. Sci. Lett. 54, 357-365.

Tatsumi, Y. (1982) Origin of high-magnesian andesites in the Setouchi volcanic belt, southwest Japan, II, melting experiments at high pressures. Earth Planet. Sci. Lett. 60, 305317.

Tatsumi, Y. (1983a) High magnesian andesites in the Setouchi volcanic belt, southwest Japan and their possible relation to the evolutionary history of the Shikoku Inter-arc Basin. Geodynamics of the Western Pacific-Indonesian Region (Hilde, T. W. C. and Uyeda, S., eds.), 331-341, Am. Geophys. Union, Washington, D.C.

Tatsumi, Y. (1983b) Volcanic geology of Shodo-Shima Island, Kagawa Prefecture, southwest Japan, and its bearing on paleoenvironment of the Seto Inland Sea area. J. Geol. Soc. Japan 89, 693-706.

Tatsumi, Y. (2001) Geochemical modeling of partial melting of subducting sediments and subsequent melt-mantle interaction: Generation of high-Mg andesites in the Setouchi volcanic belt, southwest Japan. Geology 29, 323-326.

Tatsumi, Y. and Eggins, S. M. (1995) Subduction Zone Magmatism. Blackwell, Cambridge, $211 \mathrm{pp}$.

Tatsumi, Y. and Hanyu, T. (2003) Geochemical modeling of dehydration and partial melting of subducting lithosphere: Toward a comprehensive understanding of high-Mg andesite formation in the Setouchi volcanic belt, SW Japan. Geochem. Geophys. Geosyst. 4, Paper 2003GC000530.

Tatsumi, Y. and Ishizaka, K. (1981) Existence of andesitic primary magma: an example from southwest Japan. Earth Planet. Sci. Lett. 53, 124-130.
Tatsumi, Y. and Ishizaka K. (1982) High magnesian andesite and basalt from Shodo-shima island, southwest Japan and their bearing on the genesis of calc-alkaline andesites. Lithos 15, 161-172.

Tatsumi, Y. and Maruyama, S. (1989) Boninites and high-Mg andesites: tectonics and petrogenesis. Boninites (Crawford, A. J., ed.), 50-71, Unwin Hyman, London.

Tatsumi, Y., Ishikawa, N., Anno, T., Ishizaka, K. and Itaya, T. (2001) Tectonic setting of high-Mg andesite magmatism in the SW Japan arc: K-Ar chronology of the Setouchi volcanic belt. Geophys. J. Int. 144, 625-631.

Tatsumi, Y., Nakashima, T. and Tamura, Y. (2002) The petrology and geochemistry of calc-alkaline andesites on ShodoShima Island, SW Japan. J. Petrol. 43, 3-16.

Umino, S. and Kushiro, I. (1989). Experimental studies on boninite petrogenesis. Boninites (Crawford, A. J., ed.), 89111, Unwin Hyman, London.

van der Laan, S. R., Flower, J. F. J. and Groos, A. F. (1989) Experimental evidence for the origin of boninites: nearliquidus phase relations to 7.5 kbar. Boninites (Crawford, A. J., ed.), 112-147, Unwin Hyman, London.

Volkening, J., Walczyk, T. and Heumann, K. G. (1991) Osmium isotope ratio determinations by negative thermal ionization mass spectrometry. Intern. J. Mass Spectrom. Ion Proc. 105, 147-159.

Widom, E., Kepezhinskasb, P. and Defant, M. (2003) The nature of metasomatism in the sub-arc mantle wedge: evidence from Re-Os isotopes in Kamchatka peridotite xenoliths. Chem. Geol. 196, 283-306.

Woodland, S. J., Pearson, D. G. and Thirlwall, M. F. (2002) A platinum group element and Re-Os isotope investigation of siderophile element recycling in subduction zones: comparison of Grenada, Lesser Antilles arc, and the Izu-Bonin arc. J. Petrol. 43, 171-198.

Wu, F.-Y. Walker, R. J., Ren, X.-W., Sun, D.-Y. and Zhou, X.H. (2003) Osmium isotopic constraints on the age of lithospheric mantle beneath northeastern China. Chem. Geol. 196, 107-129.

Yogodzinski, G. J., Volynets, O. N., Noloskov, A. V., Seliverstov, N. I. and Matvenkov, V. V. (1994) Magnesian andesites and the subduction component in a strongly calcalkaline series at Piip Volcano, far Western Aleutian. $J$. Petrol. 35, 163-204. 